\title{
Influence of moisture content of combusted wood on the thermal efficiency of a boiler
}

\author{
LADISLAV DZURENDA* \\ ADRIÁN BANSKI
}

Technical University in Zvolen, Faculty of Wood Sciences and Technology, Masaryka 24, 96053 Zvolen, Slovakia

\begin{abstract}
In the paper the influence of moisture content of wood on the heat losses and thermal efficiency of a boiler is analysed. The moisture content of wood has a negative effect, especially on flue gas loss. The mathematical dependence of the thermal efficiency of a boiler is presented for the following boundary conditions: the moisture content of wood $10-60 \%$, range of temperatures of emitted flue gases from the boiler into the atmosphere 120-200 C, the emissions meeting the emission standards: carbon monoxide $250 \mathrm{mg} \mathrm{m}^{-3}$, fly ash $50 \mathrm{mg} \mathrm{m}^{-3}$ and the heat power range $30-100 \%$.
\end{abstract}

Keywords: Boiler; Wood; Combustion; Thermal efficiency; Mathematical dependence

\section{Nomenclature}

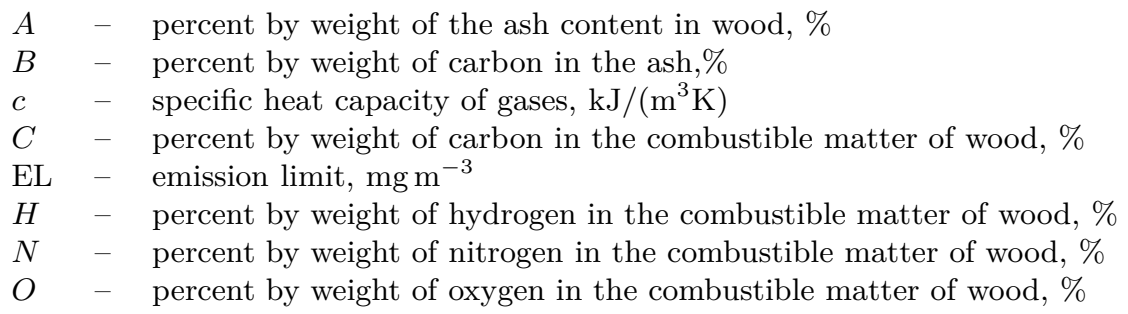

${ }^{*}$ Corresponding Author. E-mail: dzurenda@tuzvo.sk 


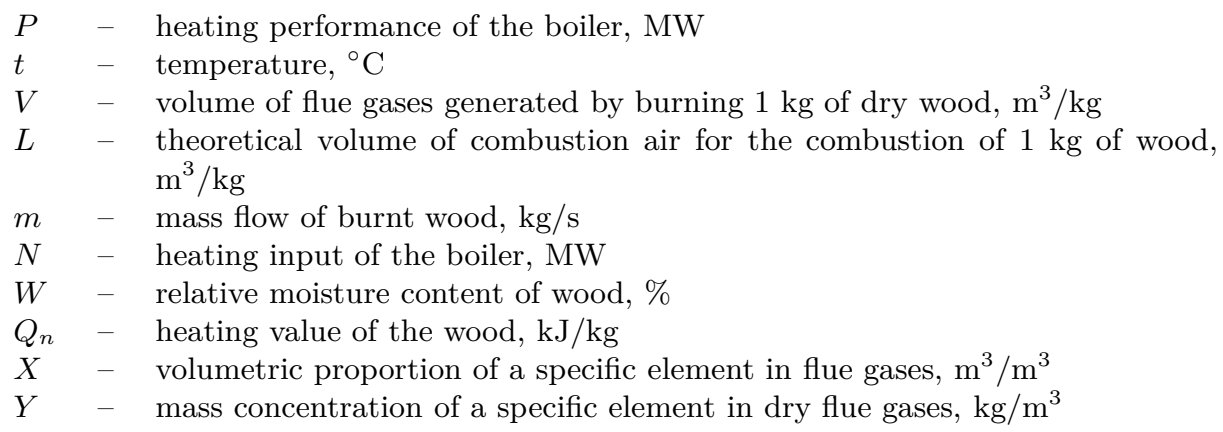

\section{Greek symbols}

$\lambda-$ coefficient of the excess of the combustion air, $\mathrm{m}^{3} / \mathrm{m}^{3}$

$\xi-$ heat loss, $\%$

$\eta \quad-\quad$ thermal efficiency, $\%$

\section{Subscripts}

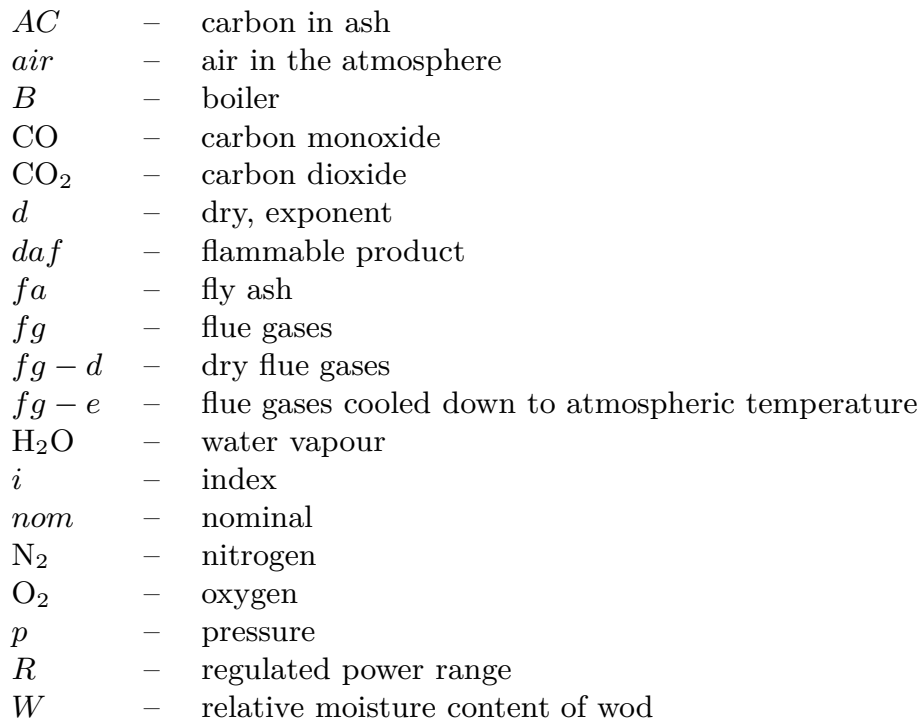

\section{Introduction}

The efficiency of heat production from biofuels-wood depends, according to [1-14], as much on the design of the heat generator as on the energy properties of wood and the actual operation of the heat generator. The energy properties of wood are crucially dependent on its moisture content, which adversely affects not only the basic energy properties, namely: upper heating value, $Q_{s}$, and lower heating value, $Q_{n}$, but also the process 
of combustion in the furnace: flame temperature, generated amount of flue gases, dew point of flue gases and emission production. The design of the exchanger of the heat generator influences the utilisation of the heat content of flue gases - the process of cooling off before their emission into the atmosphere and thus the flue gas loss, as well. Currently, boilers of medium power using wood achieve thermal efficiency of $\eta_{B}=75-85 \%$ and modern boiler units burning homogenised biofuel-wood with guaranteed energy properties achieve efficiency of $92 \%$. According to $[4,6,13,14]$, standard boiler heat losses include: flue gas loss, loss in the form of volatile combustibles and combustibles in solid residues, so called chemical and mechanical unburned carbon loss, loss by thermal radiation and convection of heat from the surface of the boiler.

The paper presents analysis of the impact of wood moisture content on the thermal loss of the boiler with a grate furnace fulfilling the criteria of the best available technologies in the European Union and the mathematical dependence of thermal efficiency of the boiler on the moisture content of wood.

\section{The model}

The thermal efficiency of the boiler is defined as the ratio of the heating capacity to the power consumption of the boiler. One way to determine it is by using an indirect method, i.e., on the basis of standard heat losses of the boiler, $\xi_{i}$, it is mathematically described by the relation:

$$
\eta_{B}=\frac{P}{m Q_{n}} 100=100-\sum \xi_{i}
$$

\subsection{Heat losses of the boiler}

Standard heat losses of the boiler producing heat by combusting solid fuel, according to $[4,6,15,16]$, include the following heat losses:

$$
\sum \xi_{i}=\xi_{f g}+\xi_{\mathrm{CO}}+\xi_{f a}+\xi_{A C}+\xi_{R}
$$

where: $\xi_{f g}$ - loss caused by the heat loss in flue gases (flue gas loss), $\xi_{C O}-$ loss caused by the volatile combustible loss in flue gases (chemical unburned carbon loss); $\xi_{f a}$ - loss caused by the involatile combustible loss in flue gases in the form of fly ash and soot, $\xi_{A C}$ - loss caused by the involatile combustible loss in solid residues (mechanical unburned carbon loss); $\xi_{R}-$ 
loss caused by thermal radiation and convection of heat from the surface of the boiler into the ambient space.

Flue gas loss the heat loss of the boiler caused by the abstraction of heat in flue gases out of the boiler into the atmosphere. It is defined as the difference between the enthalpy of flue gases emitted out of the boiler and the enthalpy of flue gases cooled down to the ambient temperature per amount of heat produced by $1 \mathrm{~kg}$ of fuel. It can be determined by the following formula [15-17]:

$$
\xi_{f g}=\frac{V_{f g} c_{p}\left(t_{f g}-t_{f g-e}\right)}{Q_{n}} 100 .
$$

Heat loss caused by loss of combustibles in flue gases - chemical unburned carbon loss $\left(\xi_{C O}+\xi_{f a}\right)$ represents the loss due to incomplete combustion of combustible matter of biofuel. It relates to the presence of: soot in fly ash, $f a$, carbon monoxide, $\mathrm{CO}$, methane, $\mathrm{CH}_{4}$ or heavier hydrocarbons $\mathrm{C}_{n} \mathrm{H}_{m}$ (tars) in flue gases emitted out of the boiler into the atmosphere. The most commonly occurring and measurable components of chemical unburned carbon loss from wood combustion are these emissions: soot in fly ash, $f a,\left(Q_{n}=32600 \mathrm{~kJ} \mathrm{~kg}^{-1}\right)$, and carbon monoxide, CO, $\left(Q_{n}=10200 \mathrm{~kJ} \mathrm{~kg}^{-1}\right)$. The calculation of heat loss caused by loss of volatile combustibles is described in the following equations [15-18]

$$
\begin{aligned}
\xi_{\mathrm{CO}} & =\frac{10200 Y_{C O} V_{f g-d}}{Q_{n}} 100, \\
\xi_{f a} & =\frac{32600 Y_{f a} V_{f g-d}}{Q_{n}} 100 .
\end{aligned}
$$

Heat loss caused by the combustible loss in solid residues - mechanical unburned carbon loss occurs due to the overflow of solid combustible matter (charcoal $Q_{n}=32600 \mathrm{~kJ} \mathrm{~kg}^{-1}$ ) through the grate into the dustbin. It only occurs in grate furnaces while burning solid fuel [1517]. The loss is presented in the formula

$$
\xi_{A C}=32600 \frac{\frac{B}{100} \frac{A^{d}}{100}\left(1-\frac{W}{100}\right)}{Q_{n}} 100 .
$$


Heat loss caused by thermal radiation and convection of heat from the surface of the boiler into the ambient space $\left(\xi_{R}\right)$ depends on the design of heat generator, wall thickness, material, insulation and surface finish. To determine the heat loss caused by thermal radiation and convection of heat from the surface of the boiler into the ambient space, in practice we use nomograms or the empirical relationship which takes into the account the operational heat output of a boiler $[5,15,17]$

$$
\xi_{R}=\frac{4}{100 \sqrt[3]{P_{\text {nom }}}} \frac{P_{\text {nom }}}{P} 100 .
$$

\subsection{Algorithm for calculating parameters of heat losses}

The following equations describe the algorithm for calculating various parameters of heat losses dependent on the chemical composition of combustible matter $\mathrm{C}^{d a f}, \mathrm{H}^{d a f}, \mathrm{O}^{d a f}, \mathrm{~N}^{d a f}$, ash content in the dry matter of wood $\mathrm{A}^{d}$, relative moisture content of combusted wood $W$ and excess of combustion air $\lambda$ :

Volume of wet flue gases from wood combustion is described in Eq. (8). The calculation of flue gas volume does not reflect the negligible amount of water vapour present in the combustion air within the process of wood combustion.

$$
\begin{aligned}
V_{f g} & =\left[1.867 \frac{\mathrm{C}^{d a f}}{100}+11.2 \frac{\mathrm{H}^{d a f}}{100}+0.8 \frac{\mathrm{N}^{d a f}}{100}+L_{a i r}(\lambda-0.21)\right] \\
& \times\left[1-\frac{A^{d}}{100}\left(1-\frac{W}{100}\right)-\frac{W}{100}\right]+1.24 \frac{W}{100} .
\end{aligned}
$$

Stoichiometric air volume for the combustion of $1 \mathrm{~kg}$ of wood (fuel does not contain sulphur):

$$
L_{a i r}=\frac{1}{0.21}\left[1.87 \frac{\mathrm{C}^{d a f}}{100}+5.6 \frac{\mathrm{H}^{d a f}}{100}+0.8 \frac{\mathrm{N}^{d a f}}{100}-0.7 \frac{\mathrm{O}^{d a f}}{100}\right] .
$$

Volume of dry flue gases produced by the combustion of $1 \mathrm{~kg}$ of wood:

$$
\begin{aligned}
V_{\mathrm{fg}-\mathrm{d}} & =\left[1.867 \frac{\mathrm{C}^{d a f}}{100}+0.8 \frac{\mathrm{N}^{d a f}}{100}+0.79 L_{a i r}+L_{a i r}(\lambda-1)\right] \\
& \times\left[1-\frac{A^{d}}{100}\left(1-\frac{W}{100}\right)-\frac{W}{100}\right] .
\end{aligned}
$$




\subsection{Mean specific capacity for the gas}

The value of the mean specific heat capacity of $1 \mathrm{~m}^{3}$ of flue gases at constant pressure is quantified by the relation:

$$
c_{p}=c_{p-\mathrm{CO} 2} X_{\mathrm{CO} 2}+c_{p-\mathrm{O} 2} X_{\mathrm{O} 2}+c_{p-\mathrm{N} 2} X_{\mathrm{N} 2}+c_{p-\mathrm{H} 2 \mathrm{O}} X_{\mathrm{H} 2 \mathrm{O}} .
$$

The following equations, according to the authors [15,17], describe the dependence of the specific heat capacity of $1 \mathrm{~m}^{3}$ of various components of flue gases on temperature:

$$
\begin{array}{ll}
\text { carbon dioxide } & c_{p-\mathrm{CO} 2}=0.0008 t_{f g}+1.6473, \\
\text { water vapour } & c_{p-\mathrm{H} 2 \mathrm{O}}=10^{-7} t_{f g}^{2}+10^{-4} t_{f g}+1.4895, \\
\text { oxygen } & c_{p-\mathrm{O} 2}=5 \times 10^{-8} t_{f g}^{2}+2 \times 10^{-4} t_{f g}+1.3036, \\
\text { nitrogen } & c_{p \mathrm{~N} 2}=9 \times 10^{-8} t_{f g}^{2}+2 \times 10^{-5} t_{f g}+1.3022 .
\end{array}
$$

where $t$ denotes temperature.

\subsection{Proportions of the flue gases component}

The volumetric proportions of the components of flue gases can be determined from the following equations $[15,17,18]$ :

Volumetric proportion of carbon dioxide in flue gases

$$
X_{\mathrm{CO}_{2}}=\frac{1.867 \frac{C^{d a f}}{100}\left[1-\frac{A^{d}}{100}\left(1-\frac{W}{100}\right)-\frac{W}{100}\right]}{V_{f g}}
$$

Volumetric proportion of nitrogen in flue gases

$$
X_{\mathrm{N}_{2}}=\frac{\left(0.8 \frac{N^{d a f}}{100}+0.79 L_{a i r} \lambda\right)\left[1-\frac{A^{d}}{100}\left(1-\frac{W}{100}\right)-\frac{W}{100}\right]}{V_{f g}}
$$

Volumetric proportion of oxygen in flue gases

$$
X_{\mathrm{O}_{2}}=\frac{0.21 L_{a i r}(\lambda-1)\left[1-\frac{A^{d}}{100}\left(1-\frac{W^{r}}{100}\right)-\frac{W^{r}}{100}\right]}{V_{f g}}
$$

Volumetric proportion of water vapour in flue gases

$$
X_{\mathrm{H}_{2} \mathrm{O}}=\frac{11.2 \frac{H^{\text {daf }}}{100}\left[1-\frac{A^{d}}{100}\left(1-\frac{W}{100}\right)-\frac{W}{100}\right]+1.24 \frac{W}{100}}{V_{f g}}
$$




\subsection{Heat value of biomass}

The heat value of biomass depending on its moisture content is

$$
Q_{n}=18840-21353 \frac{W}{100} .
$$

\subsection{Input data}

In order to make the process of analysing the impact of wood moisture content on the operational efficiency of the boiler with a grate furnace more effective, a program was developed in EXCEL in tabular form which is based on the following input data:

- $C^{d a f}, H^{d a f}, O^{d a f}, N^{d a f}$ - chemical composition of combustible wood,

- $W$ - relative moisture content of wood,

- $A^{d}$ - ash content of wood,

- $\lambda$ - excess combustion air,

- $t_{e}$ - air temperature in the atmosphere,

- $t_{f g}$ - flue gas temperature at the boiler outlet,

- $B$ - proportion of carbon in ash,

- $Y_{\mathrm{CO}}$ - mass concentration of carbon monoxide $\mathrm{CO}$,

- $Y_{f a}$ - mass concentration of ash and soot in dry flue gas,

which provide information about thermal efficiency of the boiler and the extent of heat losses in the boiler.

\section{The results}

The given mathematical model of the impact of moisture content of wood on heat loss and thermal efficiency of the boiler applies to wood with the chemical composition of the combustible matter: $C^{d a f}=0.5 \pm 0.01 \mathrm{~kg} \mathrm{~kg}^{-1}$, $H^{\text {daf }}=0.06 \pm 0.001 \mathrm{~kg} \mathrm{~kg}^{-1}, O^{\text {daf }}=0.44 \pm 0.03 \mathrm{~kg} \mathrm{~kg}^{-1}$, and with ash content $A^{d}=0.01 \mathrm{~kg} \mathrm{~kg}^{-1}$.

Table 1 presents values of heat losses and thermal efficiency for a boiler burning wood with the following moisture content values: $W=10 \%, W=$ $30 \%$, and $W=60 \%$, at the excess of the combustion air $\lambda=2.1$, the average temperature of the combustion air blown in the furnace of the boiler $t_{\text {air }}=$ 
$10^{\circ} \mathrm{C}$, the temperature of the flue gases emitted out of the heat generator $t_{f g}=120^{\circ} \mathrm{C}$ and $t_{f g}=200^{\circ} \mathrm{C}$ at a rated output and concentration of carbon monoxide values $Y_{\mathrm{CO}}=250 \mathrm{mg} \mathrm{m}^{-3}$ and fly ash with level of $Y_{f a} \leq$ $50 \mathrm{mg} \mathrm{m}^{-3}$, i.e., at the level of the emission limit.

Table 1: Heat losses in the boiler due to the moisture content of the combusted wod with the noisture content of $W=10 \%, 30 \%$, and $60 \%$ and the temperature of flue gases $t_{f g}=120{ }^{\circ} \mathrm{C}$ and $t_{f g}=200^{\circ} \mathrm{C}$.

\begin{tabular}{|l|r|r|r|r|r|r|}
\hline Parameter & \multicolumn{5}{|c|}{ Heat loss of the boiler [\%] } \\
\hline \hline Flue gas temperature $\left(_{f g}\right)$ & \multicolumn{3}{|c|}{$120{ }^{\circ} \mathrm{C}$} & \multicolumn{3}{|c|}{$200{ }^{\circ} \mathrm{C}$} \\
\hline Relative moisture content $(W)$ & $10 \%$ & $30 \%$ & $60 \%$ & $10 \%$ & $30 \%$ & $60 \%$ \\
\hline Flue gas loss $\left(\xi_{f g}\right)$ & 8.37 & 9.09 & 12.43 & 15.19 & 16.51 & 22.55 \\
\hline $\begin{array}{l}\text { Heat loss caused by the volatile com- } \\
\text { bustible loss in flue gases }\left(\xi_{C O}\right)\end{array}$ & 0.13 & 0.14 & 0.17 & 0.13 & 0.14 & 0.17 \\
\hline $\begin{array}{l}\text { Heat loss caused by the involatile } \\
\text { combustible loss in flue gases }\left(\xi_{f a}\right)\end{array}$ & 0.17 & 0.18 & 0.22 & 0.17 & 0.18 & 0.22 \\
\hline $\begin{array}{l}\text { Heat loss caused by the involatile } \\
\text { combustible loss in the ash }\left(\xi_{A C}\right)\end{array}$ & 0.18 & 0.19 & 0.23 & 0.18 & 0.19 & 0.23 \\
\hline Thermal efficiency $\left(\eta_{b}\right)$ & 91.15 & 90.40 & 86.97 & 84.33 & 82.98 & 76.83 \\
\hline
\end{tabular}

The analysis of the impact of wood moisture content on heat loss has shown that the greatest heat loss of the boiler is the flue gas loss at both temperatures of flue gases $t_{f g}=120^{\circ} \mathrm{C}$ and $t_{f g}=200^{\circ} \mathrm{C}$. Wood moisture content causes increasing heat flue gas loss at the temperature of flue gases $t_{f g}=120{ }^{\circ} \mathrm{C}$ from $\xi_{f g-w 10 \%}=8.37 \%$ to $\xi_{f g-w 60 \%}=12.43 \%$, i.e. by $\Delta \xi=$ $4.06 \%$, and at the temperature of flue gases $t_{f g}=200{ }^{\circ} \mathrm{C}$ from $\xi_{f g-w 10 \%}=$ $15.19 \%$ to $\xi_{f g-w 60 \%}=22.55 \%$, i.e., by $\Delta \xi=7.36 \%$. The other heat losses, such as volatile or involatile combustible loss in flue gases or mechanical unburned carbon loss, are much smaller in comparison with the flue gas loss and the impact of moisture content does not exceed $\Delta \xi=0.05 \%$.

Figure 1 presents the impact of wood moisture on the heat efficiency of the boiler for flue gas temperature $t_{f g}=120^{\circ} \mathrm{C}$ and $t_{f g}=200^{\circ} \mathrm{C}$. The presented dependence of a temperature of emitted flue gases into the atmosphere $t_{f g}=120^{\circ} \mathrm{C}$ is mathematically described by the 2 nd degree polynomial in the form:

$$
\eta_{B(W)}=\left[-0.001 W^{2}-0.019 W+91.526\right] .
$$




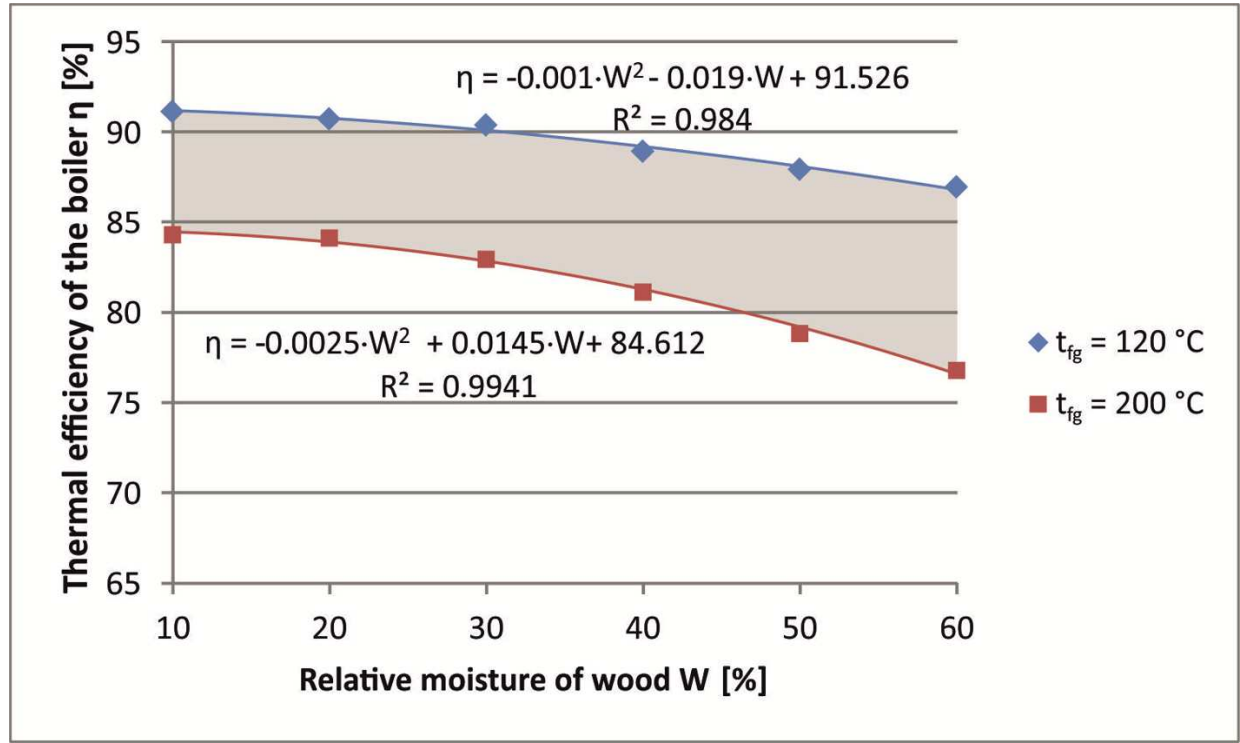

Figure 1: The impact of wood moisture on the heat loss of the boiler during combustion at the excess of the combustion air $\lambda=2.1$ and the temperature of flue gases emitted out of the boiler $t_{f g}=120{ }^{\circ} \mathrm{C}$ and $t_{f g}=200{ }^{\circ} \mathrm{C}$.

The influence of increasing flue gas temperature on the decrease of thermal efficiency of a boiler combusting firewood from value $t_{f g}=120^{\circ} \mathrm{C}$ to flue gas temperature $t_{f g}=200^{\circ} \mathrm{C}$ is quantified by the equation

$$
\begin{aligned}
\eta_{B(W-t)} & =\left[-0.001 W^{2}-0.019 W+91.526\right] \\
& -\left[(0.001 W+0.058)\left(t_{f g}-120\right)\right] .
\end{aligned}
$$

The boiler heat loss caused by emission and convection of heat from the boiler surface is not primarily dependent on firewood moisture content, but the values depending on the boiler size are not negligible. Boilers with the heat output $P=5 \mathrm{MW}$ have stated heat loss $\xi_{R}=2.3 \%$ and boilers with a heat output $P=10 \mathrm{MW}$ have stated heat loss $\xi_{R}=1.8 \%$. The operation of boilers at a lower heat output than the rated power /within the authorized regulation of manufacturer/ is accompanied by an increase of specified heat loss of the boiler and the decline of overall thermal efficiency. In the interval of the permitted control range of boilers $R=30-100 \%$ there is the increase of heat loss of $5 \mathrm{MW}$ within nominal boiler output from a value $\xi_{R}=2.3 \%$ to $\xi_{R}=7.8 \%$ when operating at a heat output of $30 \%$. A similar increase of the boiler heat loss is also observed within the boil- 
ers with a heat output of $10 \mathrm{MW}$. The heat loss of the boiler compared to operating at the nominal output changes from the value $\xi_{R}=1.8 \%$ to $\xi_{R}=6.2 \%$.

When accepting the above facts, the dependence of the thermal efficiency of boilers burning firewood with the moisture content $W=10-60 \%$, at a temperature of flue gas emitted from the boiler into the atmosphere $t_{f g}=120-200^{\circ} \mathrm{C}$ and regulated heat output in the range $R=30-100 \%$ is mathematically described by the equation

$$
\begin{aligned}
& \eta_{B}=\left[-0.001 W^{2}-0.019 W+91.526\right] \\
& \quad-\left[(0.001 W+0.058)\left(t_{f g}-120\right)\right]-\frac{4}{P} \sqrt[3]{P_{n o m}^{2}} .
\end{aligned}
$$

\section{Conclusions}

The presented analyses the impact of moisture content of the combusted firewood on the heat loss and thermal efficiency of boilers with a grate furnace fulfilling the criteria of the best available technology (BAT) in the European Union.

Increased moisture content of firewood has a negative influence on the thermal efficiency of the boiler. Within combustion of firewood with moisture content $\mathrm{W}=10 \%$, at a temperature of flue gas emitted from the boiler to the atmosphere $t_{f g}=120^{\circ} \mathrm{C}$ the boiler achieves thermal efficiency $\eta_{B-10 \%}=91.1 \%$, while burning firewood with the moisture content $\mathrm{W}=$ $60 \%$ within the same operating conditions leads to a decline of thermal efficiency to $\eta_{B-60 \%}=86.9 \%$, i.e., in $\eta_{B}=4.2 \%$.

Increasing temperature of emitted flue gas leads to an even more significant decline of the boiler thermal efficiency. The combustion of firewood within the moisture content range $\mathrm{W}=10-60 \%$, at the temperature of emitted flue gas to the atmosphere $t_{f g}=200^{\circ} \mathrm{C}$, is accompanied by a decrease of boiler thermal efficiency of $\eta_{B}=7.5 \%$.

Based on analyses performed, the mathematical dependence of boiler thermal efficiency is set for the moisture content of combusted firewood in the range $\mathrm{W}=10-60 \%$, at the temperature of flue gas emitted from the boiler to the atmosphere $t_{f g}=120-200^{\circ} \mathrm{C}$ for boilers with a heat output $P=5-10 \mathrm{MW}$ fulfilling the criteria of emissions at the level of the emission limit values of carbon monoxide: $E L_{\mathrm{CO}}=250 \mathrm{mg} \mathrm{m}^{-3}$ and the ash: $E L_{f a}=50 \mathrm{mg} \mathrm{m}^{-3}$. 
The presented dependence of boiler thermal efficiency on the moisture content of combusted firewood in a grate furnace might be helpful for operators of boilers for quick and approximate determination of effective heat production from firewood in a form of thermal efficiency of a boiler.

Acknowledgments The present contribution was developed under the research of a grant project: KEGA- SR Nr: 006TU Z-4/2014, as a result of the authors work and a significant assistance of the Cultural and Educational Grant Agency of the Ministry of Education, Science, Research and Sport of the Slovak Republic.

Received 5 October 2016

\section{References}

[1] Golonkov S.I., Koperin I.F., Najdenov V.I.: Energy use of wood of wastes. Lesnaja promyšlennos', Moscow 1987 (in Russian).

[2] Neuenschwander P., Good J., Nussbaumer Th.: Combustion efficiency in biomass furnaces with flue gas condensation. In: Proc. Biomass for Energy and Industry, 10th European Conference and Technology Exhib., 8-11 June 1998.

[3] Marutzky, R., Seeger K.: Energy from wood and other biomass. DRD - Verlag , Leinfelden-Echterdingen. 1999 (in German).

[4] Domanski M., Dzurenda L., Jablonski M., Osipiuk J.: Wood as a material energetic. SGGW, Warszawa 2007 (in Polish).

[5] Dzurenda L., JandačKa J.: Energy utilization of dendromass. TU Zvolen, Zvolen 2010 (in Slovak).

[6] Dzurenda L., Bartko M., Ridzik L.: Energetic characteristics green chips made of branches of wood species Popolus $x$ Euroamericana clone Koltay grown on plantatioons. Acta Facultatis Xylologiae Zvolen 54(2012), 2, 115-122 (in Slovak).

[7] Nosek R., Holubcík M., JandačKa J.: The impact of bark content of wood biomass on biofuel properties. BioResources 11(2016), 1, 44-53.

[8] ZiĘBIK A., GŁadysz P.: Influence of biomass cofiring on the optimal coefficient of the cogeneration share in a district heating system. Arch. Thermodyn. 35(2014), 1, 99-115, DOI: 10.2478/aoter-2014-0007.

[9] Rimár M., Fedák M., Korshunov A., Kulikov A., Miž'Aková A.: Determination of excess air ratio during combustion of wood chips respect to moisture content. Acta Facultatis Xylologiae Zvolen 58(2016), 2, 133-140, DOI: 10.17423/afx.2016.58.2.14

[10] Dzurenda, L., PŇAkoviČ L.: Combustion characteristics of biofuels - fallen leaves of hardwood deciduous trees. Acta Facultatis Xylologiae Zvolen 57(2015), 1, 119-126 (in Slovak). 
[11] Nosek R., Holubcík M.: Energy properties of air dry firewood. Acta Facultatis Xylologiae Zvolen 58(2016), 1, 105-112, DOI: 10.17423/afx.2016.58.1.10 (in Slovak).

[12] Dzurenda L.: Model of heat load on the atmosphere by flue gases. Manufacturing Technology 15(2015), 5, 804-808.

[13] Hroncová E., Ladomerský J., Valíček J., Dzurenda L: Combustion of Biomass Fuel and Residues: Emissions Production Perspective. In: Developments in Combustion Technology 2016, http://dx.doi.org/10.5772/63793.

[14] Dzurenda L., Ladomerský J., Hroncová E.: Conversion factor of fuel-bound nitrogen to oxides in the process of spruce wood combustion in boiler grate furnaces. Pol. J. Environ. Stud. 24(2015), 2, 505-509, DOI:10.15244/pjoes/27408.

[15] Rajniak I. et al:: Thermo- energetic and emission measurements. Ister Science, Bratislava 1997 (in Slovak).

[16] HoloubeK D.: Combustion equipment, heat exchangers and boilers. Ars Litera, Košice 2002, (in Slovak).

[17] Dzurenda L., Banski A.: Dependence of the boiler flue gas losses on humidity of woody biomass. Arch. Thermodyn. 36(2015), 4, 77-86, DOI: 10.1515/aoter-20150034 .

[18] Dzurenda L., Banski A.: Production of heat and power from woody biomass. TU Zvolen, Zvolen 2016 (in Slovak).

[19] Kollmann F.: Technology of wood and wood-based materials. Vol. I. Band. BerlinGöttingen-Heidelberg-Munchen 1951 (in German).

[20] Simanov V.: Energy use of wood. Terapolis, Olomouc 1995 (in Czech).

[21] JandačKa J., Malcho M., Mikulík M.: Biomass as an Energy Source. GEORG, Žilina 2007 (in Slovak). 